\title{
Nöropazarlama Uygulamalarının Etik Bağlamında Değerlendirilmesi
}

\author{
Gül Coșkun Değirmen ${ }^{1}$ \\ Emine Șardağı ${ }^{2}$ \\ Öz
}

Pazarlama alanı sürekli değişmekte ve tüketiciyi etkileme konusunda yeni yaklaşımlar ortaya çıkmaktadır. Tüketiciyi anlamak, onların zihninde yer edinmek ve bunu kalıcı hale getirmek bilinçlenen tüketici yapısından dolayı giderek zorlaşmaktadır. $\mathrm{Bu}$ nedenle son dönemlerde pazarlama dünyasındaki en çarpıcı gelişmelerden biri bilimle pazarlamanın kesiştiği nokta olarak değerlendirilen nöropazarlama alanında gerçekleşmektedir. Etik konusu sadece pazarlama alanında değil, yıllardır farklı disiplinlerde sürekli tartışılan konulardan biri olmuştur. Ancak tüketici davranışlarını anlamak için bilimin kullanılması, tüketicinin karar verme mekanizmalarının ortaya çıkarılması firmalar açısından bakıldığında önemli avantajlar sağlasa da gizlilik temelinde bazı sorunları da beraberinde getirmektedir. Bu çalışma, pazarlama akademisyenleri bakış açısıyla bu zamana kadar yapılan ancak eksik noktaları olduğunu düşündüğümüz tartışmalara katkı sağlamak ve çok yeni bir konu olması nedeniyle şu andaki bilgilerimiz çerçevesinde nöropazarlamanın yaratacağı etik sorunlara yönelik düşünceleri kuramsal bir değerlendirme ile ortaya koymaktadır. Çalışma ile özellikle nörologların bu konuda eleştirel davranmalarına rağmen bu alandaki akademisyenlerin nöropazarlamaya bakış açıları değerlendirmeye alınmıştır. Bu zamana kadar yapılan çalışmalara bakıldığında nöropazarlamanın reklam ve pazarlamada nasıl uygulandığına ve hangi araçların kullanıldığına yönelik araştırmalar yapılmış ve bunların sonuçları paylaşılmıştır. Araşıırmada "Nöropazarlama etik açıdan ne kadar uygun?", "Bilimde kullanılan tekniklerin pazarlama amaçlı kullanılması doğru mudur?", "Nöromarketing çalışmaları sonucunda elde edilen bilgiler ne kadar güvenilir ve tutarlıdır?,", "Nöropazarlama tekniklerinin pazarlama alanında sağlayacağı avantajlar nelerdir?" sorularına cevap aranmaya çalışılmıştır.

Anahtar Kelimeler: Nöropazarlama, Etik, Pazarlama.

\section{Evaluation of Neuromarketing Practices In Terms Of Ethical Context}

\begin{abstract}
Marketing industry constantly changes and creates new tools to impress consumers. It is getting harder to understand the consumer, get imprinted on their minds and to become permanent because of the consumer structure that gets more conscious. Therefore, one of the most spectacular innovations in the marketing world has recently been in neuromarketing field, where science intersects marketing. The concept of "ethics" has constantly been discussed not only in marketing field, but also in different disciplines for years. However, even though using science to understand the consumer
\end{abstract}

1 Yrd. Doç. Dr. Ege Üniversitesi, İletişim Fakültesi

2 Arş. Gör. Anadolu Üniversitesi, İletişim Bilimleri Fakültesi 
behaviours, revealing the decision-making mechanisms of the consumers provide significant advantages for companies, they also bring some problems in terms of confidentiality. This research has the goal to contribute to the discussions, which we believe to have missing points from the perspective of marketing academicians, and to project a conceptual evaluation upon the ideas about how neuromarketing would create ethical problems with the information in hand, since it is a new subject. The research primarily evaluates the opinions of academicians on neuromarketing, even though neurologists have a critical approach on this field. Considering the researches that have been carried out on neuromarketing, the researches have mainly been on how neuromarketing was applied in advertisement and marketing and which tools have been used and the results were revealed. The research tries to find answers to the questions of "How appropriate is neuromarketing in terms of ethics?", "Is it appropriate to apply scientific techniques for marketing purposes?", How reliable and consistent are the data obtained by neuromarketing practices?", "What are the advantages to be provided by neuromarketing techniques in marketing field?".

Keywords: Neuromarketing, Ethics, Marketing 


\title{
Giriș
}

\begin{abstract}
S on yıllarda beyin görüntüleme tekniklerinin gelişmesi ve tıp alanının dışında da uygulanması tüketici davranışları ile ilgili yeni araştırma yollarının bulunmasına katkı sağlamıştır (Pop vd., 2014:27). Pazarlama uygulayıcıları ve akademisyenleri heyecanlandıran bu gelişmeler aynı zamanda ciddi görüş ayrılıklarını, tartışmaları da beraberinde getirmiştir. Bu tartışmaların en başında ise etik uygunluk gelmektedir. Birçok nörobilimci nöro tekniklerin pazarlamada kullanımına etik açıdan karşı çıkmakta, tüketicinin "beynindeki satın alma düğmesini" (buy button in the brain) bularak bireyin direnemeyeceği reklâm kampanyaları ortaya çıkarmanın etik olarak uygun olmadığını belirtmektedir. Literatüre bakıldığında bu zamana kadar yapılan çalışmalarda nöropazarlamanın, bilim ile pazarlamanın birleşimi sonucunda tüketicinin karar merkezlerine etki eden faktörleri bulmada önemli veriler sunduğundan bahsedilmektedir. Ancak; nörolojide kullanılan elektronik aletlerin satın alma davranışını etkileme ve ticari amaçlı kullanılması, tüketicinin ne istediğinin elektronik cihazlarla belirlenmeye çalışılmasıının etik açıdan uygunluğu ve bunun ortaya çıkaracağı sonuçlar göz ardı edilmiştir.
\end{abstract}

\section{Nöropazarlamanın Kavramsal Çerçevesi}

Nöropazarlama; birbirinden farklı disiplinler olan, psikoloji, sosyoloji, pazarlama ve nörolojiyi bir araya getiren, tüketicinin satın alma kararı verirken "rasyonel olmayan", "irrasyonel olan kararlarını" inceleyen bir alandır. Tüketici bu irrasyonel kararları; duygusal, dürtüsel ve beş duyu organımızın algıladığı uyarıcılara göre vermektedir (Yücel ve Çubuk, 2013: 173). Nöropazarlama kavramı, 1990 yılının ikinci yarısında, ilk kez Harvard Üniversitesi'nden Prof. Gerry Zaltman'ın işlevsel manyetik tınlaşım (rezonans) cihazını (fMRI) pazarlama araştırmalarında kullandığını duyurmasıyla gündeme gelmiştir. Bu çalışmaları, 2002 yılında nöropazarlama kavramı ile ifade eden ise Prof. Ale Smidts'tir (Ural, 2008: 422-423).

Nöro bilimin uygulamalı bir uzantısı olan nöropazarlama aslında beyin-tarama teknolojisinin pazarlama alanına uygulanmasıdır. $\mathrm{Bu}$, nöro bilim ile tüketici davranışlarının çalışmalarının birleştirildiği gelişmekte olan bir alandır. Nöropazarlama beyin açısından tüketiciye bakarak değerini arttırmaktadır (Sreedevi vd., 2013: 65).

Lee ve arkadaşları nöropazarlamayı; "pazarlar ve pazarlama değiş tokuşlarıyla (exchange) ilgili insan davranışını anlamak ve analiz etmek için nöro bilim yöntemlerinin kullanıması" olarak tanımlamaktadır (2007: 199-204). Bu tanım nöropazarlamanın niyetini göstermesi açısından iki noktada önemlidir. Birincisi, nöropazarlamayı işletmelerin yalnızca ekonomik çıkarları için nöro görüntüleme tekniklerini kullanan bir yaklaşım olmaktan çıkarmaktadır. İkincisi, nöropazarlama araştırmalarının alanını genişleterek yalnızca tüketici davranışları değil örgütler arası ilişki araştırmaları gibi pazarlama akademik yazınındaki ortak birçok ilgi alanıyla ilişkilendirmektedir (Ural, 2008: 425).

Ariely ve Berns (2010) nöropazarlama kavramının son dönemlerde iki sebepten dolayı artan bir popülerlik kazandığını belirtmişlerdir. Bunlardan birincisi olarak diğer yöntemlere göre daha ucuz ve hızı sonuç alabilmeyi mümkün kılmakta; ikinci olarak da pazarlamacılara geleneksel metodları kullanarak elde edemeyecekleri gizli kalmış bilgileri sunmasından kaynaklanmaktadır. 
Nörobilim uygulamaları insanların günlük yaşamlarında satın aldıkları ürünler, hatırladıkları markalar, markayı hafızalarında geri çağırmaları ile ilgili olarak çeşitli noktalarda sinyaller aracılığıyla temel bilgilere ulaşılabilmesini kolaylaştırmaktadır. Elde edilen bilgiler doğrultusunda yapılan pazarlama çalışmalarının tüketiciyi olumlu ya da olumsuz etkileyip etkilemediği ortaya konulmaktadır.

Ural'a (2008) göre; pazarlamanın bu yeni alanı, ürüne karşı beynin tepkilerini ölçmekte tıbbi teknolojileri kullanmaktadır. Beyin bölgelerinde beliren etkinliklerin değişimini ölçmek yalnızca tüketicilerin neden o ürünü seçtiklerini değil, aynı zamanda hangi beyin bölümünün bu seçimde etkin olduğunu göstermektedir.

Nöropazarlama, klasik pazarlama yöntemlerini ve pazarlama araştırmalarının vazgeçilmez anketlerini geride bırakarak Fonksiyonel Manyetik Rezonans Görüntüleme (FMRI) tekniği ile tüketicinin beynine girip hangi reklam öğesine hangi tepkiyi verdiğini ayrıntısıyla raporlamaktadır (Tüzel, 2010: 165). Böylelikle tüketicinin geleneksel yöntemler kullanılarak yapılan pazar araştırmalarına verdikleri cevapların tutarlılığı ortaya konulmaktadır. Tüketiciler; anket, focus grup vb. yöntemlerin kullanılarak yapıldığı araştırmalarda gerçek duygu ve düşüncelerini paylaşmakta ya da ortaya çıkarmakta tereddüt yaşayabilmektedir. Bu nedenle pazar araştırmalarında Nöro teknikleri kullanmak, bireyin gerçek düşüncesini gösterebilmesi, sözel olarak ifade ettiği ile gerçek düşüncesi arasındaki farkın ortaya çıkarılmasını sağlayarak araştırmacılara ve firmalara önemli bilgiler sunmaktadır.

Wilson vd. (2008) nöroteknolojilerin kullanılmasının tüketicilerin duygusal tepkilerini olumlu yönde tetiklemek için pazarlamacılar tarafından üretilen bilgilendirici olmayan ya da yanlış bilgileri içeren içeriklerin tekrar düzeltilmesini, revize edilmesini mümkün kıldığını belirtmektedir.

“Nöronal pazarlama” sinir bilimleri (neuroscience)'nin bir dalı olarak nöronlardaki etkileşimleri inceleyip insanların farkında olmadıkları, dile getirilmemiş, algı, intiyaç, dürtü ve arzularını açığa çıkarmayı amaçlamaktadır. Kısaca satın alma eğilimlerimizi, beynimizin nasıl çalıştığını ve nasıl karar verdiğimizi bilimsel tekniklerle ölçen ve açıklamaya çalışan bir kavramdır (Müdok, 2013).

Nöropazarlamaya yönelik yapılan uygulamalardan en bilineni Baylor Tıp Fakültesi'nde bir grup araştırmacının Coca Cola ve Pepsi'nin tüketiciler tarafından tercih edilme oranları ve nedenlerini belirlemeye yönelik yapmış oldukları çalışmadır. Söz konusu deneyde 67 uygulamacıya marka isimleri gösterilmeden içecekler sunulmuş ve hangisini tercih ettiklerini belirtmeleri istenmiştir. Test sonucunda çalışmaya katılanların \%75'i Pepsi'yi tercih ettiğini belirtmiş ancak kolayı içmeden sadece marka adı gösterildiğinde bu sefer deneklerin \%75’i Coca Cola'yı tercih etmiştir. Araştırmacılar testler esnasında deneklerin beyin taramalarını yapmışlar ve Coca Cola markasının deneklerin beynindeki hatırlamadan ve kendim-imajından (self-image) sorumlu merkezinin aşırı bir şekilde aktifleştiğini keşfetmişlerdir (Ural, 2008: 423-424). Nöropazarlamanın gelişiminde önemli bir yere sahip olan bu araştırma, tüketicilerin kimi markalarla aralarında kurdukları duygusal bağın tercihlerini önemli noktada etkilediğini ve bu nedenle de beyinlerinde çeşitli hareketlenmelerin ortaya çıkmasına neden olduğunu göstermektedir. Ünlü sinir bilimci Damasio’nun insanların kararlarının genellikle rasyonel değil, duygusal süreçler sonrasında oluştuğu iddiası da göz 
önünde bulundurulduğunda geleneksel araştırma yöntemlerinin çoğu zaman yetersiz kaldığı ve tüketicilerin bilinçsiz kararlarını açıklamakta zorlanan pazar araştırmalarında kullanılan yöntemlerin değişime uğraması gerektiği sonucu çıkarılabilmektedir. (http:// www.pazarlamadunyasi.com/ Default.aspx?tabid=5408\&ltemld=719).

2011 yılında 111 pazarlama akademisyeni, 52 nörolog ve 56 pazarlama uzmanı ile yürütülen bir çalışmada, nöropazarlamanın ihtiyacın olmadığı ürün ya da hizmetin satın alınmasını sağlayan bir yol olmadığı tüm katılımcılar tarafından kabul görmüştür. Katılımcılar tarafından üç faktör -ilgi ve katılım, bilgi ve farkındalık ve etik nöropazarlamanın en önemli yönleri olarak algılanmıştır. Araştırma sonucunda pazarlama uzmanları ve nörologların nöropazarlamaya akademisyenlere göre daha olumlu baktıkları ortaya çıkmıştır (Eser vd., 2011: 854).

Nöropazarlamanın temeli; nörobilimci Antonio Damasio'nun bireylerin karar verirken beyinlerinin rasyonel kısımlarını değil, duygusal kısımlarını kullanarak karar verdikleri iddiasına dayanmaktadır (Tüzel, 2010: 166). Çünkü duygularımız değer unsurlarını kodlama aracımız olarak görülmekte ve bizi duygusal yönden yakalayan markalar bireyler tarafından - Apple,Harley Davidson ve L'Oreal gibi markalar- her seferinde mutlaka galip gelmektedir. Burada unutulmaması gereken nokta; beyinde gerçekleşen işlemlerin çoğunun bilişsel değil duygusal olduğudur (Lindstrom, 2008: 36).

Lindstrom (2008)'e göre; nöropazarlamacılar, beş duyu organının gönderdiği veriler doğrultusunda beynin satın alma karar sürecini incelemekte ve geleceğin markalarının yaratılmasında önemli bir rol oynamaktadırlar. Bu nedenle pazarlamacıların beynimizde bizim belli markaları satın almaya yönelten nedenleri bulduğunda ya da beynin bu noktada nasıl bir işleyiş gösterdiğini bildiklerinde geleceğin markalarının yaratılmasında önemli bir avantaj elde edecekleri düşünülmektedir.

Nöropazarlamanın niyeti; bireylerin, grupların ve organizasyonların pazarla ilgili davranışlarını daha iyi anlamak, açıklamak ve tahmin etmektir (Lee, vd., 2007: 199204). Nöropazarlamanın niyetine ilişkin tartışmalar, The Lancet dergisinin Şubat (2004: 71) sayısında Donald Kennedy'nin yazısındaki “beyin görüntüleme, bireyin özel yaşam hakkını kabul edilemez bir düzeyde ihlal etme yolu olarak kullanılacaktır" ifadesiyle alevlenmiştir (Ural, 2008: 425). Bu düşüncenin temelinde, pazarlama araştırmalarının ticari bir faaliyet ve topluma ürün satmak amacıyla tasarlandığı görüşü yatmaktadır. Tüketicilerin zihnini okumak; pazar araştırmacıları için bilim kurgu dünyasına girmek gibi görünse de, gerçekte pazarlamacılar ve medya mensupları bu yeni pazarlama tekniğini kullanarak tüketicilerin satın alma davranışlarını etkileyen unsurları tespit edebilmektedir (Tüzel, 2010: 165). Nöro-pazarlama beyindeki sinir mekanizmalarının reklam ve pazarlama amaçlı olarak kullanılmasında beyindeki sinir merkezlerinin nasıl uyarılacağı konusuna odaklanmaktadır (Hatip, 2008).

Bir ürüne karşı beynin tepkileri ölçülürken farklı beyin bölgelerinde beliren aktivitenin değişimini ölçmek; yalnızca tüketicilerin neden o ürünü seçtiklerini değil, aynı zamanda hangi beyin bölümünün bu seçimde etkin olduğunu da medikal anlamda ortaya koymaktadır. Yani tıp, sinir sisteminin sırlarını birer birer ortaya çıkarmaktadır. Beynin uyaranlara, iletilere ve reklâmlara verdiği tepkilerin fiziki yapısını anlamak günümüzde mümkün olmakla birlikte ilerleyen, hızla sayısallaşan tıp teknolojisi sayesinde de sonuçları anlamlandırmak giderek kolaylaşmaktadır (Müdok, 2013). 
Nöropazarlama yöntemleri, işletmelerin ürettiği mal ve hizmetleri tüketicilere daha fazla satabilmek, tüketici zihninde kalıcı olmak ve tüketicinin satın alma eğiliminde neleri tercih edeceğini belirlemek ve etkili bir reklam pazarlama stratejisi oluşturmak için kullanılmaktadır (Yücel ve Çubuk, 2014: 222). Nöropazarlamaya göre; tüketiciler aslında herhangi bir ürün ya da hizmeti satın alma kararı verirken sadece beynin rasyonel kısmı olan mantıksal kısma göre hareket etmemekte, aynı zamanda beynin irrasyonel yani duygusal kısmı da verdiği kararlarda etkili olmaktadır.

Nöropazarlamanın kurumlar açısından gelecekte daha fazla kullanılmaya başlayacağı görüşü yaygın olmakla birlikte, buna yönelik bütçe ayrımlarına daha fazla yer verileceği öngörülmektedir. Ancak burada karşılaşılması muhtemel sorunlardan en önemlileri, yüksek maliyet, araştırma için gerekli katılımcı bulma zorluğu ve etik konusunda giderek artan kaygılar olarak sıralanmaktadır. Ayrıca dikkate alınması gereken unsurlardan birtanesi de nöropazarlamanın geleneksel araştırma yöntemlerini tamamen ortadan kaldıracak ya da ona rakip olacak bir yöntemler dizisi olmadığıdır. Doğru şekilde kullanıldığında nöro tekniklerle elde edilen sonuçlar, geleneksel metotları destekleyerek daha doğru bilgilere ulaşıımasına katkıda bulunmaktadır.

\section{Etik ve Nöropazarlama Illișkisi}

İnsan eylemlerini konu alan etik, eylemi ahlaki açıdan iyi bir eylem yapan niteliksel durumu sorgulamakta ve bu bağlamda ahlak, iyi, ödev, gereklilik ve izin gibi kavramları içermektedir (Özdemir, 2009: 120). Pazarlama araştırmasında etik konusu, 1960'ların sonu 1970'lerin başlarındaki tüketici hareketinin ve işletme toplulukları içindeki işletme sosyal sorumluluklarının farkına varılması sonucunda 1960'larda literatürde de büyük ilgi çekmeye başlamıştır (Özdemir, 2009: 122).

Etik sadece pazarlama alanında değil iletişim, sosyoloji, politika, sosyoloji gibi birçok alanda tartışmalara yol açmış bir konudur. Tüketici ya da hedef kitleye yönelik uygulamalar etik konusunun sorgulanmasını beraberinde getirmiştir. Pazarlama araştırmasındaki etik konular genellikle iki nedenden kaynaklanmaktadır. Birincisi; araştırmacılar araştırma esnasında kamuoyu ile sık sık ilişki kurma durumunda olup kamudan elde edilen bilginin duygusal ya da yanlış anlamda kullanılma riski ile karşı karşıya olunmasıdır. İkincisi ise; çoğu pazarlama araştırmasının ticari endişelerle gerçekleştiriliyor olmasıdır (Özdemir, 2009: 123).

Nöropazarlamanın yaratabileceği en dikkat çeken sorunlardan biri, neden olduğu etik kaygılar olarak görülmektedir. Bu kaygılardan ilki, araştırmalarda yer alan deneklerin/gönüllülerin bilgilendirilme ve güvenlik haklarına yönelik iken ikincisi ise; bilgiyi elde eden şirketlerin bu bilgileri kullanım hakkıyla ilgili etik kaygılardır. Diğer bir deyişle, bir şirketin veya ticari bir kuruluşun aldığı bu tür bilgileri ne ölçüde, hangi sınırlar içinde kullanma hakkı vardır? Beyin ve sinir sisteminden alınan verilerin analiz edilmesi, geleneksel araştırma yöntemlerine ve elde edilen bulgulara daha farklı bir açıdan bakılmasını sağlamıştır. Ancak, araştırma şirketlerinin bu alanla ilgilenerek araştırmaların sektöre yönelik bir çıktı sağlaması etik açıdan eleştirilere yol açmıştır (Çakar ve Ülman, 2011: 328).

Nöropazarlamaya getirilen baskılar algılanan tehlikeye yönelik olarak yapılmaktadır. Endişelerin temelinde; nöropazarlamada kullanılan teknolojilerin etkili bir şekilde tüketici 
davranışlarını yönlendirmek için kullanılırsa bu durumun bir gün bireyin özerkliğini kaybetmesinde tehlike yaratacağı yatmaktadır. Ayrıca üniversiteler ve tıp uzmanlarının nöropazarlama şirketleri ile ortaklıklar kurması eleştirilerin diğer yönünü oluşturmaktadır. Ancak reklamcıların ya da markaların bu teknikleri kullanarak tüketicinin satın alma düğmesini bulabilmesi bir tehlike olarak ele alınsa da bu endişelerin büyük olasılıkla henüz erken olduğunu ifade eden görüşler de belirtilmektedir. Nöropazarlamaya iyimser açıdan bakanlar; mevcut teknolojiler sayesinde tüketici tercihlerinde gizli kalmış bilgilerin ortaya çıkarılması ve markaların pazarlama amaçlarının yönelik yatırımlarını değerlendirebilmelerine katkı sağlayacağını düşünmektedir (Fisher vd., 2010).

Etik açıdan bakıldığında, niyetin ya da sonucun iyi olması, sonuca ulaşmada kullanılan yöntem yanlış olduğu sürece doğru değildir (Laczniak, 1983: 66-80). Nöropazarlamanın etik olup olmadığına yönelik farklı düșünenler açısından bakıldığında; eleștirenler bu yöntemlerin insan zihnine hükmetmek anlamına geldiği için zararlı olduğunu düşünmekte, destekleyenler ise; insanların karar alma süreçlerinde etki eden faktörleri bilmenin onları kontrol altına almak anlamına gelmediğini savunmaktadır. Burada önemli olan nokta; katılımcıların kendilerine uygulanacak yöntemler ve içerik hakkında yeterince bilgi sahibi olmalarının sağlanmasıdır.

Nöropazarlamanın ilgilendiği; reklam kampanyaları yapmak için tüketicinin satın alma düğmesi olarak tanımlanan "buy buton"u bulmak ve tüketicinin direnemeyeceği çalışmaları oluşturmaktır. Bu noktada tüketici koruma gruplarının asıl korkusu; uygulamaların deneklerde savunmasız bir şekilde uygulanması ve bunun spesifik nörolojik etkilere yol açabileceğinden kaynaklanmaktadır (Burgos vd., 2013: 524).

Genel olarak bakıldığında, temelde ticari anlamda bir çıkar elde etmek ve ilerletmek için bilimsel teknolojinin kullanımı özünde sorun olarak görülmemektedir. Bu noktada Garrett tarafından ortaya atılmış ve geniş kabul görmüş etik kuram temelinde nöropazarlamanın yöntemi irdelendiğinde, kötü niyet ve amaçlarla kullanılmamak koşulu ile etik olduğu söylenebilir (Ural, 2008: 425). Burada önemli olan, firma yetkililerinin deneklerde çeşitli teknikleri kullanarak elde ettikleri bilgileri hangi gizlilik koşulları çerçevesinde ve ne ölçüde kullandıklarının belirlenmesidir. Çünkü teknolojinin kullanımı insan beyninin iç çalışma prensibini ortaya koymaktadır. Bu sayede geleneksel yöntemler kullanılarak yapılan araştırmalarda tüketicinin verdiği yanıt ile bilimin kullanılarak yapılan araştırmalarda çıkan sonuçlar karşılaştırılma imkânı elde edilmektedir. Böylelikle tüketicinin beli koşullar altında verdiği cevaplar ile gerçekteki duygu ve düşünceleri belirlenmekte ve bu doğrultuda beyindeki belli noktaları etkilemeye yönelik mesajlar oluşturulmaya çalışılmaktadır.

Pop ve arkadaşlarına (2014) göre; nöropazarlamanın etik boyutu; pazar araştırması alanında uygulanması ile ilgili en büyük ve en hassas sorunlardan biridir. Nöropazarlama bir bilim olarak ortaya çıkmasından beri araştırmacılar arasında birçok tartışmayı ve etik sorunu gündeme getirmiştir. Bu tartışmaların bir kısmı, bazı yazarların nöropzarlama tekniklerinin insan zihnine yapılan izinsiz giriş için büyük bir potansiyel olduğuna inanmasından kaynaklanmaktadır. Her alanda olduğu gibi nöropazarlama da şiddetli savunuculara ve eleştirmenlere sahiptir. Savunucularına göre nöropazarlama; hem şirketler hem de alıcılar için yararlıdır. Çünkü insanlar tarafından gerçekten istenen ürünlerin geliştirilmesine katı sağlayacaktır. Öte yandan eleştirenlere göre nöropazarlama, satın alımlar konusunda insanların bilinçli kararlar almalarını tehlikeye atacaktır (Pop vd., 2014: 30). 
Morin (2011); nöropazarlamaya yönelik etik durumların ortaya çıkmaya devam edeceğini ancak nöropazarlama araştırmalarının saygı ve şeffaflık ile yürütülmesiyle ilgili standartların benimsendiğini ifade etmektedir.

Nöropazarlamaya eleştirel olarak bakan bazı nörologlar, uygulanan yöntemlerin sadece tüketicinin daha fazla tüketmesini nasıl sağlayabiliriz? sorusunu cevaplamaya çalıştıklarını dolayısıyla insanların yararına bir iyilik olmadığını savunmaktadır. Nöro teknik yöntemlerini kullanan firmalar ise; yaptıkları uygulamalar ile amaçlarının insanların kendilerini nasıl daha mutlu hissetmelerini sağlayabileceklerini ortaya çıkarmak olduğunu savunmaktadır. Nöro teknikler kullanılarak yapılan araştırmalar ile geleneksel yöntemler kullanılarak fark edilmeyen noktalar gözlemlenebilmekte ve gereken düzeltmeler yapılabilmektedir.

Nöropazarlamanın etik gelişimi, araştırma deneklerinin korunmasını, kullanılan teknolojilerin arka planının kamuya doğru bir şekilde sunulmasını gerektirmektedir. Pazarlama amaçlı araştırmalarda bu konuda boşluklar bulunmaktadır. Federal destekli araştırma merkezlerinde, nörolojik görüntüleme çalışmalarına gönüllü katılan denekler, Kurumsal Değerlendirme Kurulu talimatlarıyla korunmaktadır. Bu talimatlar, çoğu görüntüleme teknolojisi Gıda ve İlaç İdaresince (FDA)denetimli tıbbi cihazlar olarak kabul edilmesinden dolayı katı kurallar içermektedir. Ticari girişimlerde ise, deneklerin mahremiyeti bu ölçüde korunamayabilir, özellikle pazarlama amaçlı çalışmalardaki kısıtlamaların gevşekliği endişe verici boyuttadır. Buna ek olarak, yeni teknolojiler geliştiğinde, var olan korumalar da kaybedilebilir (Murphy vd., 2008: 295).

Medyanın nöropazarlamaya karşı sansasyonel yaklaşımı; insanların yeni teknolojilere güvenini arttırmaktır. Bazı medya kayıtları bunu tüketicinin zihnindeki satın alma düğmesine basmak olarak nitelendirmektedir. Belli bir dereceye kadar bu, insanların beyinlerinde sahtekarlık yapmaya izin vermekte ve belirli bir şirketin lehine olarak ürün veya hizmetini satın alma kararları manipüle edilebilmektedir (Pop vd., 2014: 30).

Wilson ve arkadaşları (2008), bireyin satın almadaki seçim özgürlüğünün nöropazarlama ile yönlendirilmesini etik açıdan değerlendirmektedir. Nöropazarlama araştırmaları sadece pazarlama mesajı ya da belli bir ürün ile ilgili duyguları tanımlamakla kalmamakta, aynı zamanda duygu ve gönderilen mesaj arasında bir korelâsyonun oluşmasına da katkıda bulunmaktadır. Etik sorun tam da bu noktada ortaya çıkmaktadır. Çünkü tüketiciden ürün ve özelliklerine yönelik olarak alınan tepkiler bunun gelecekte satış arttırma amaçlı kullanılmasına izin vermektedir. Bu durumda nöropazarlama araştırmalarının tüketicinin intiyacını karşılamak için değil, satış amacını gerçekleştirmek için yapıldığı ortaya çıkmaktadır (Pop vd, 2014: 31).

Ticari amaçla bilimin kullanılması özünde bir sorun olarak görülmemektedir. Ancak; burada dikkat edilmesi ve etik açıdan düşünülmesi gereken nokta, teknolojinin insan beyninin çalışma yapısını ortaya çıkarmak için kullanılmasıdır. Nöropazarlamanın, şirketlere müşterilerini etkileme gücü verirken; müşterilerin gerçek isteklerini anlamak için doğru yöntem olup olmadığı önemli sorunlardan biri olarak görülmektedir. Nöropazarlama çalışmalarının gelecekteki etkilerine yönelik yapılan araştırmalarda yüksek maliyet, katılımcı bulma ve etik sorunlar nöropazarlama çalışmalarında en önemli faktörler olarak ortaya konmuştur (Eser vd, 2011: 860).

Pazarlamada, nöro tekniklerin kullanılıp kullanılmaması konusunda ciddi tartışmalar 
ve görüş ayrılıkları yaşanmaktadır. Nöropazarlamaya karşıt olan pazarlama akademisyenlerine göre, nörobilim ve bilişsel psikoloji genel olarak tehlikeli boyutları olan konular arasında yer almaktadır (Lee vd., 2006: 199-204).

Nöropazarlama çalışmalarında önemli olan; araştırmanın hangi ihtiyaca yönelik olarak, hangi bilimsel koşullar ve zeminden yararlanarak yapıldığı; yapılan araștırmaların hangi bilimsel hedeflere yönelik ve gerekçelerle planlandığı, nasıl bir bilimsel yönteme ve araştırma protokolüne dayalı olarak yürütüldüğü; katılımcıların bedensel ve ruhsal sağlığını, esenliğini gözetmek üzere ne gibi koşulların ve tedbirlerin sağlandığının ilk başta sorgulanmasıdır. Tüm bu hazırlık süreci; bağımsız çalışan, nesnel, yansız karar alan etik kurulların denetiminde işlemelidir (Çakar ve Ülman, 2012: 331).

Pazarlama akademisyenlerinin nöropazarlamaya olumlu baksalar dahi bu teknikleri kullanmayı bilemeyecekleri ileri sürülmektedir. Nöro bilimciler ise, bu tekniklerin pazarlamada kullanım amacına etik açıdan karşı çıkmaktadır (Ural, 2008: 422).

$\mathrm{Bu}$ açıdan bakıldığında; nöropazarlama ile ilgili olarak farklı görüşlerin olduğunu söylemek mümkündür. Burada nöropazarlama tekniklerinin hangi niyetle kullanıldığı konusu karşımıza çıkmaktadır. Bu açıdan önemli olan araştırmaya konu olan/olacak deneklerin yapılan bu deneylerin amaçları konusunda tam olarak bilgilendirilmesidir.

\section{Araștırma: Nöropazarlama Uygulamalarının Etik Bağlamında Değerlendirilmesi}

\subsection{Araștırmanın Konusu}

Araştırmanın konusu, Türkiye'de Nöropazarlama üzerine çalışmalar yürütenlerin nöropazarlamanın etik boyutu üzerine olan görüşleri ve nöropazarlamada kullanılan yöntemlerin etik açıdan nasıl bir yere sahip olması gerektiğidir.

\subsection{Araștırmanın Önemi ve Amacı}

$\mathrm{Bu}$ araştırmanın amacı " nöropazarlamada kullanılan yöntemlerin etik açıdan ne kadar doğru olduğu" sorusuna cevap bulmaktır. Türkiye'de nöropazarlama konusunda akademik çalışmalar yapılmış olmasına rağmen etik boyutuna yönelik yeterli bir çalışma bulunmamaktadır. Bu nedenle bu çalışma ile konuya ilişkin bir araştırma ortaya konularak literatüre katkı sağlamak amaçlanmaktadır.

\subsection{Araștırmanın Metodolojisi}

Nöropazarlamanın etik açıdan değerlendirmesine yönelik bu çalışmada nitel araştırmanın durum çalışması stratejisi tanımlayıcı tekniği ile ortaya çıkarılmaya çalışılmıştır. Bu tekniğin seçilmesinin nedeni; konunun kendi çerçevesi içerisinde tam anlamıyla değerlendirmesini sağlamaktır. Ayrıca nitel araştırma yöntemi çerçevesinde etik kavramı olmak üzere tek bir kavram üzerinde odaklanılmış ve elde edilen veriler yorumlanarak aktarılmıştır.

\subsection{Araștırmanın Sınırlılıkları}

$\mathrm{Bu}$ araştırmada elde edilen bulgular aşağıda belirtilen sınırlılıklar altında toplanmış ve bu noktalar göz önünde bulundurularak veriler yorumlanmıştır. 
- Çalışma, Türkiye'de çeşitli üniversitelerde nöropazarlama alanında çalışan akademisyenlerle sınırlıdır.

- Çalışmaya veri oluşturabilecek alanda çalışma yapmış kişilerin sayısının azlığı daha detaylı bilgiye ulaşılması noktasında bir sınırlılık oluşturmaktadır.

- Bu çalışmanın genel alanı nöropazarlamanın etik boyutuyla ilgilidir.

\subsection{Araștırmanın Evren ve Örneklemi}

Çalışma kapsamında amaçlı örneklem yöntemlerinden biri olan ölçüt örnekleme tercih edilmiştir. Araştırma sürecinde belirlenen durumların derinlemesine çalışılmasına olanak veren amaçlı örneklemde önceden tanımlanarak belirlenmiş amaca uygun birimler incelenmek için seçilmektedir (Erdoğan, 2008). Ölçüt örnekleme yöntemi; araştırma amacının somut göstergeler dahilinde net olarak irdelenebildiği, önceden belirlenen ölçütler aracılığı ile katılımcıların belirlenmeye çalışıldığı ve bir dizi ölçütü karşılayan durumların çalışılmasıdır. Ölçüt örneklemde, araştırma sürecinde katılımcılar açısından ölçüt olarak nitelendirilecek kriterler araştırmacı tarafından oluşturulabildiği gibi daha önceden var olan bir ölçüt listesi dâhilinde de oluşturulabilmektedir (Yıldırım ve Şimşek, 2008). Bu çalışma için örneklem ölçütü; katılımcıların tamamının akademik bir unvana sahip olması ve daha önceden nöropazarlama ile ilgili bilimsel bir çalışmada bulunmaları olarak belirlenmiştir. Çalışmaya yönelik bu ölçütleri kapsayan katılımcıları belirlemek için ASOS (Akademia Sosyal Bilimler Indeksi) ve Anadolu Üniversitesi veritabanları "nöromarketing, neuromarketing, nöropazarlama" arama kriterleri Türkçe ve İngilizce olarak taranmıştır. Yapılan veri tabanı taramaları sonucunda çalışmanın yapıldığı tarihe kadar geçen süreç içerisinde Türkiye'de farklı üniversitelerde çalışan akademisyenler tarafından nöropoazarlama konusunda yapılmış toplamda 20 (yirmi) çalışmanın olduğu belirlenmiştir. Bu doğrultuda yapılan bu araştırma; kendi alanında farklı akademik unvanlara sahip ve daha önceden bu alanda çalışma yapmış kişilerle gerçekleştirilmiştir.

\subsection{Veri Toplama Yöntemi}

Araştırma için kullanılacak veriler e-posta yoluyla toplanmıştır. Katılımcıların nöropazarlama ve etik konusundaki düşüncelerini alabilmek için toplamda 8 tane önceden yapılandırılmış açık uçlu soru e-posta aracılığıyla katılımcılara gönderilmiştir. Verilerin toplanma sürecinde ilk olarak, veritabanları kullanılarak konu ile ilgili yapılan araştırmalara ulaşılmıştır. İkinci aşamada ise; araştırma yapan bu kişilerin akademik unvanları belirlenmiş ve son olarak üniversiteleri aracılığıyla kendileri ile telefonla görüşülerek konu ile ilgili öncelikle bir ön bilgilendirme yapılmıştır. Telefonla ulaşılamayan akademisyenlere mail aracılığı ile ulaşı ımaya çalışılmış ve bu doğrultuda gelen bildirimler dikkate alınmıştır.

20 Kasım-20 Aralık 2014 tarihleri arasında daha önce kendileri telefonla aranarak ya da mail yoluyla ulaşılarak konu hakkında bilgilendirilen katılımcıların mail adreslerine daha önceden hazırlanmış açık uçlu sorular gönderilmiş ve kendilerinden cevaplamaları istenmiştir. Açık uçlu sorular sayesinde katılımcıların yöneltilen soruları kendi cümleleriyle ifade etmesi ve konu hakkında sorulan sorular çerçevesinde bir değerlendirmede bulunmaları amaçlanmıştır. Çalışma kapsamında gönderilen maillere cevap alınamaması ya da katılımcıların unutabilme ihtimalleri göz önünde bulundurularak bir defalık olmak üzere geri dönüş alınamayan katılımcılara 15 gün 
içinde tekrar hatırlatma maili gönderilmiştir. Verilerin toplanması ve analiz süreci; katılımcıların yoğunluğu, hemen geri dönüşte bulunamamaları, zaman sıkıntısı vb. nedenlerden dolayı yaklaşık altı ay sürmüştür.

Gönderilen maillere belirlenen tarihler sonunda 2 Profesör, 3 Doçent, 5 Yardımcı Doçent, 2 Araştırma Görevlisi tarafından toplamda 12 kişiden geridönüş alınabilmiş, katılımcıların 2 tanesi çalışmaya katılamayacağını belirtmiş, 6 tanesinden ise; telefon ve maillere herhangi bir geri dönüş alınamamıştır.

\subsection{Verilerin Analizi (Bulgular)}

Nöropazarlama uygulamalarının etik açıdan değerlendirilmesini oraya çıkarmak için yapılan araştırma sonucunda katılımcılara sekiz tane açık uçlu soru yöneltilmiştir. Elde edilen veriler derlenerek çalışmaya dâhil edilmiştir. Sorular ve bulgular şu şekildedir:

\section{Nöropazarlamayı nasıl tanımlamaktasınız?}

Katılımcılar, nöropazarlamayı yeni bir uygulama olarak görmekle birlikte tüketicinin davranışını anlamlandırmada, bireylerin marka hakkındaki düşüncelerini ve algılarını nörobilimdeki çeşitli teknikleri kullanarak kendilerine değil, beyinlerine sorarak daha somut veriler ortaya çıkmasını sağlayan bir uygulama olduğunu belirtmişlerdir. Nöropazarlamanın; birbirinden farklı disiplinler olan psikoloji, sosyoloji, pazarlama ve nörolojiyi biraraya getiren ve tüketicinin satın alma kararı verirken rasyonel değil, irrasyonel olan kararlarını incelemeyi sağlayan bir yöntem olduğu ifade edilmiştir. Katılımcılara göre, nöro teknik uygulamalar bugüne kadar pazarlama materyallerinin ve yöntemlerinin tüketici üzerindeki etkisini çeşitli deneylerle ölçerek reklam verenlere kolaylık sunmakta ve tüketicilerin beyinlerindeki satın alma düğmelerinin bulunmasını sağlamaktadır. Çalışmaya katılan akademisyenlere göre; fMRI, EEG, Eyetracking gibi yöntemler ile beynin hangi pazarlama öğesine(reklam, PR etkinlikleri, ürünler, hizmetler, ambalajlar) nasıl tepki verdiği tespit edilebilmekte ve bu da hedef kitleye sunulacak mesajın içeriğinin, şeklinin belirlenmesi konusunda reklam verene önemli bilgiler sunmaktadır. Nöropazarlama, geleneksel araştırma yöntemlerinden daha derin bilgi sağlamakla birlikte beynin elektriksel aktivitesinin ölçülmesiyle insan beyninin nasıl çalıştığı ve hangi durumlarda ya da koşullarda ve hangi uyaranlar neticesinde nasıl kararlar aldığını, bu kararları verirken beynin hangi uyarı bölgesini harekete geçirdiğini bilimsel tekniklerle ölçerek ortaya çıkaran, günümüzde müşteri kazanmanın, piyasalarla ilgili değişen insan davranışlarını anlamlandırmanın ve analiz etmenin sinirbilimsel bir yöntemi olarak görülmektedir.

Nörologların bilimin ticari amaçla kullanılmasına yönelik olarak çeşitli kaygılar taşıdığı bilinmektedir. Bu noktada bilimin pazarlama amaçlı kullanılması hakkında sizin görüşleriniz nelerdir?

Nörologların bilimin ticari amaçla kullanılmasına yönelik olarak çeşitli kaygılar taşıdığı bilinmektedir. Bu noktada akademisyenlerin bakış açılarına bakıldığında birbirinden farklılıklar görülmekle birlikte genel anlamda böyle bir kaygıdan uzak oldukları yönünde bir görüş hâkimdir. Araştırmaya katılan birçok akademisyene göre, nöroteknik uygulamaların pazarlama amaçlı kullanılmasında herhangi bir sakınca bulunmamaktadır. Çünkü pazarlama, reklam ve tüketici davranışları açısından 
değerlendirildiğinde bilim ve bilimsel veriler zaten işletmeler, marka yöneticileri tarafından tüketicileri satın almaya teşvik etmek amacıyla pazarlama amaçlı yıllardır kullanılmaktadır. Buna göre; pazarlamanın temel problemi, hedef kitlenin beklentilerini tanımlamaktır. Katılımcılar değer ifade eden önerilerin bulunması noktasında daha iyi tanımlama yapmaya olanak sağlayacak yöntemlerin kullanılmasını bir olumsuzluk olarak görmemektedir. Nöropazarlama aslında beyne direkt mesaj iletmez ve emir vermez, bunun yerine gönderilen mesajların ne kadar etkin olduğunu ölçmeye yardımcı olmaktadır. Bu nedenle çalışmaya katılan birçok akademisyene göre; tüketicileri satın almaya yönelten yolu bulmalarında ve satın almada nasıl karar verdiklerinin araştırılmasında, anlaşıımasında yardımcı bir araç olarak görülen nöroteknik uygulamalar etik ilkeler ve yan etkiler dikkate alınarak kullanıldığında herhangi bir olumsuzluk teşkil etmemektedir.

Bunun yanı sıra katılımcılar arasında, nöropazarlama uygulamaları büyük bütçeli yatırımların etkinliğini kampanya öncesinde öngörebilme imkânı sağlamaya yardımcı olduğu için markaların bütçelerini araştırma sonuçlarına göre daha rasyonel yapma imkânına sahip olmalarını sağladığı ve özellikle uyuşturucu, sigara ile mücadelede, trafik kazalarına karşı duyarlılık, yardım kampanyaları, eğitim, kadına şiddet gibi pek çok konuda nöropazarlama araştırma yöntemleri kullanılarak etkili sonuçlar alınabileceğine yönelik görüşler de yer almaktadır.

Katılımcılar arasında bilimin pazarlama amaçlı kullanılması hakkındaki olumsuz görüşe göre ise, beynimizin ne düşündüğü ve ne tepki verdiğinin kişiye özel olması ve bunun başkaları tarafından araştırma konusu olmaması gerektiği konusunda görüşler yer almaktadır. Özellikle tüketicilerin mahremine girilmesinin uygulamanın etik açıdan sorgulanmasına neden olduğu belirtilmektedir. Bununla birlikte elde edilen bilgilerin ticari amaçlı olarak yine tüketici üzerinde kullanılması bir olumsuzluk olarak görülmektedir. Ayrıca; nöroteknik uygulamalarda kullanılan cihazların radyasyon içermesi ve ticari amaç için insanları bu radyasyona maruz bırakmanın çok doğru bir davranış olmadığı savunulmaktadır.

Nöropazarlama tekniklerinin denekler üzerinde uygulanması için karşılığında kimi zaman ücret ödenmesi sonuçların tutarlılık ve güvenirliliğini nasıl etkilemektedir?

Araştırmada yer alan nöropazarlama tekniklerinin denekler üzerinde uygulanması için karşılığında kimi zaman ücret ödenmesi sonuçların tutarlılık ve güvenirliliğini nasıl etkileyeceği sorusuna ise araştırmadaki katılımcılar arasında çoğunluğu etkilemeyeceği yönünde olsa da yine de görüş farklıı̆ğı bulunmaktadır.

Bu doğrultuda deneklere ücret ödenmesini savunanlara göre; sıradan araştırmalara katılanlara da küçük ya da sembolik ücretler ödenmektedir. Bunun nedeni denek bulma güçlügü̈nden dolayı sadece katılımcı sayısını arttırmaktır. Özellikle beyinle ilgili araştırmalar katılımcılarda ister istemez bir tedirginlik yaratmaktadır, ancak bu durumun insan beyninin vereceği tepkiyi değiştirmeyeceği belirtilmektedir. Geleneksel araştırma yöntemlerinde denekler sözlü olarak verdikleri cevaplarda araştırmayı yapan ya da soruları soran kişiler tarafından yönlendirilebilmektedir. Örneğin anket gibi klasik bir yöntemde ücret ödenmesi halinde verilen cevaplarda sapmalar olabilmektedir. Katılımcılara göre; nöropazarlamanın diğer tüketici araştırmalarına kıyasla öne çıkmasında, insanların beyinlerindeki hareketliliği ya da ışıldayan bölgeleri kontrol edememeleri, yönlendirememeleri ve beyni direkt görüntülemeleri yatmaktadır. 
Böylelikle deneğin söylemi değil, beynin aktifleşen bölgesi saptanmaktadır ve beyindeki tepkilerin ölçülmesine birey kendi iradesi dâhilinde müdahale edememektedir. Bu yüzden, beyinden elde edilecek veriler sözel olarak elde edilen verilere göre daha güvenilir olmaktadır. Çünkü geleneksel araştırmalarda deneklerin beyanı esas iken, nöropazarlama araştırmalarında beyindeki çeşitli bölgelerin etkileşim ve reaksiyonların analizi söz konusu olmakta bu da kișinin manipülasyonunu zorlaștırmaktadır. Bu nedenle katılımcılar, eğer araştırma objektif olarak yönetilirse o araştırmada deneklere ödenen ücretin sonuçların tutarlılık ve güvenirliliğini etkilemeyeceğini düşünmektedir. Ayrıca katılımcılar; sadece ülkemiz de değil tüm Avrupa ve Amerika ülkelerinde araştırmalara katılanlara ücret ödendiğini ve bu durum gönüllülük esasına aykırı gibi gözükse de sürdürülebilirliği sağlamak konusunda en makul çözüm olarak görüldüğünü belirtmektedirler. Tüm bunlar göz önüne alındığında, her ne kadar deneklere ücret ödense de beynin yalan söyleyemeyeceği varsayımı altında sonuçların güvenirlik ve tutarlıığına etkisi olmadığı/olmayacağı yaygın bir görüş olarak düşünülmektedir.

Araştırmaya katılan ve deneklere ücret ödenmesinin sonuçların güvenirlilik ve tutarlılığını olumsuz etkileyeceğini düşünenler, bu görüşlerini deneklerin böyle bir uygulamanın içinde yer alması, uygulama öncesinde kendilerine baştan bir ücret ödenmesi zihinsel bir değişikliğe yol açmakla birlikte yapılan çalışmanın içeriği ve sonuçları üzerinde birtakım şüpheli yaklaşımları ya da daha fazla veri sağlayabilme yönünde farklı tepkileri beraberinde getireceğini temeline dayandırmaktadırlar.

Nöropazarlama tekniklerinin pazarlama amaçı kullanılmasının sağlayacağı avantajlar nelerdir?

Nöropazarlama tekniklerinin pazarlama amaçlı kullanılmasının sağlayacağı avantajlara yönelik katılımcılara yöneltilen soruda ise genelde benzer görüşler dile getirilmiştir. $\mathrm{Bu}$ açıdan bakıldığında, duyguları ölçme ve anlamanın önemi iş dünyasında çok önemli bir yere ulaşmış durumdadır. Günümüzde ürün ve hizmetlerin kalite-maliyet açısından belirli bir noktada sabitlendiği görülmektedir. Dolayısıyla markalar açısından farkılık yaratabilecek nokta, artık ürüne yapılacak yatırım olarak düşünülmektedir. Nöropazarlama bu farklılığı kendi doğasına uygun bir şekilde pazarlama amaçlı kullanarak tüketicinin belki de kendinin bile farkına varmadığı belirli noktalarına temas ederek satın alma davranışına yöneltebilecek argüman olarak kullanmakta ve firmaya avantaj sağlamaktadır.

Katılımcılar tüketici yönünde oluşturulacak marka algısının marka kimliğine yapılacak yatırımlar neticesinde ortaya çıkacağını belirtmektedir. Nöropazarlama tekniklerinin pazarlama amaçı kullanımında işletmeler için ilk amaç hedef kitlenin anlaşılmasıdır. Bu noktada nöropazarlama uygulamalarının sağlayacağı temel avantaj, müşteri intiyaçlarının tespit edilmesiyle ilgilidir. Bununla birlikte kullanılan tekniklerle elde edilen bilgiler doğrultusunda işletmelerin bütçelerini ve hedef kitlesiyle olan iletişim etkinliğini doğru ve zamanında kullanılmasını olanaklı hale getirmesine imkân sağlamaktadır. Özellikle teknolojik gelişmelerle beraber insanlardaki satın alma eğilimlerinin sürekli değișiklik göstermesiyle bu değişimleri yakalamada nöropazarlamanın sağlıklı veriler sunduğu ve işletmelerin intiyacını karşılamaya yardımcı olduğu katılımcılar tarafından savunulmaktadır. Ayrıca, tüketici tercihlerinin doğru ölçümlenmesini sağlayan nöropazarlamanın, işletmelerin stratejik kararlar almalarını kolaylaştırdığı ve geleneksel pazarlama araçlarına göre sapma oranlarını azaltan bir avantaj sunduğu belirtilmektedir. 
Katılımcılara göre; nöropazarlama uygulamalarının sağlayacağı avantajlar arasında, tüketicilerin satın alma kararını nasıl verdikleri, bu kararları nelerin etkilediği gibi konulara ışık tutması başta gelmektedir. Bununla birlikte tüketicilerin fiyat algısının ortaya koyması, güvenin ölçülmesi, etkili mağaza tasarımı, etkili reklam mesajlarının oluşturulması, reklam mesajlarına verilen tepkilerin, reklamın hatırlanırlılığının ve çekiciliğinin ölçülmesi, medya araçlarının seçimi, ürün yerleştirmenin etkinliği, ürün tasarımı ve ambalajlama kararlarının verilmesi konusunda firmalara avantajlar sağlamakta ve işe yaramayacak uygulamalarla vakit kaybetmeyi önlemektedir. Ayrıca, disiplinler arası çalışmayı sağlayacağı, üniversite-sanayi işbirliğini yakınlaştıracağı ve ürün piyasaya sürülmeden önce tüm aşamalarıyla takip edilip böylelikle boşa gidecek yatırımların önüne geçilmesine yardımcı olacağı dile getirilmektedir. Nöropazarlama uygulamalarının tüketicilerin herhangi bir manipülasyona maruz kalmadan uyarıcı ile karşılaştığında gerçekten ne hissettiği ve düşündüğünü daha net bir şekilde görüp yorumlanmasına yönelik olarak işletmelere önemli veriler sunduğu belirtilmektedir.

Nöropazarlama uygulamaları pazarlama iletişiminde özellikle geleneksel araştırma yöntemlerinin yanıltıcı sonuçlarını ortadan kaldırarak tüketici davranışlarını gerçekte neyin şekillendirdiğini somut bir şekilde sunabilmektedir. Pazar araştırmalarında özellikle tüketici davranışlarını araştıran veri toplama sürecinde deneklerin her zaman gerçekleri paylaşmadıkları bilerek ya da bilmeyerek gerçek davranış motivasyonu konusunda yanıltıcı cevaplar verdikleri bugün yadsınmaz bir gerçek olarak düşünülmektedir. Bu açıdan bakıldığında nöropazarlama araştırmaları sayesinde tüketici davranışları ve bu davranışların dinamikleri geleneksel veri toplama ve analiz etme yöntemlerine göre çok daha somut bir şekilde ortaya konulduğu savunulmaktadır.

Ayrıca katılımcılar nöropazarlama araştırmalarının kullanılması araştırmalarının sonucunda müşterilerin akıllarından geçenleri ya da ne isteklerini önceden tahmin edip, ona göre ürün sunmayı hedefleyen pazarlama uygulamalarını olanaklı hale getirdiğini belirtmektedir. Özellikle beyindeki ödüllendirme uyaranlarının neler olduğu ve uyaranları harekete geçirecek, görsel, işitsel mesajların neleri içermesi gerektiği gibi temel unsurların nöropazarlama araştırmaları sonucunda artık birer sır olmaktan çıktığı belirtilmektedir. Bu noktada önemli olan araştırmaların sonucunu doğru değerlendirebilmek için deneklerden elde edilecek verilerin doğru bir şekilde yorumlanmasıdır. Yanlı olarak yapılan ya da yapılacak olan yorumların işletmeye ya da markaya herhangi bir fayda sağlamayacağı düşünülmektedir.

İnsanların daha mutlu olması ve gerçekte ne istediklerinin daha iyi anlaşılması için kullanılan bir yöntem olduğu iddia edilen Nöropazarlamaya etik ve ahlaki açıdan nasıl bakıyorsunuz?

Araştırmaya katılanlara yöneltilen bir diğer soru çalışmanın amacını oluşturan nöropazarlamaya etik açıdan nasıl bakıldığıdır. Katılımcılardan elde edilen veriler genel anlamda olumlu yöndedir. Bu konuda elde edilen bilgilere göre; işletmeler kar elde etmek, faaliyetlerini sürdürmek ve satışlarını arttırmak için çeşitli bilimsel araştırma yöntemlerini kullanmaktadır. Kar amacı güden kuruluşlar kendi çıkarlarına uygun düşecek şekilde birçok araştırmadan faydalanmaktadır. Dolayısıyla nöropazarlama araştırmalarının diğer araştırma türlerinden bir farkı olmadığı düşünülmektedir. Ancak durum; bilim ve araştırmadan uzaklaşarak rahatsız edici bir boyutta ticari kaygı taşıyan bir niteliğe bürünürse etik açıdan eleştirilecek bir durumun ortaya 
çıkabileceği belirtilmektedir. İşletmelerin daha fazla satış yapabilmek için tüketicileri kobay olarak kullanması, tüketicinin farkında olmadan bilinçaltına müdahale ederek onları satın almaya yönlendirmesi doğru bir yaklaşım olarak görülmemektedir. Burada önemli olan; uygulamaya katılan deneklerin araştırmanın amacı, süreci, araştırmanın kimler tarafından yürütüleceği gibi konularda bilgilendirilmesi, elde edilen verilerin ne amaçla ve nasıl kullanıldığıdır. Araștırmaya katılan katıımcılar yalan beyanlar, eksik bilgilendirme konularının etik açıdan eleştirilecek konular arasında yer aldığını belirtmektedir. Bu açıdan bakıldığında; etik ilkelere bağlı kalındığında ve nöropazarlamanın uygulama alanı içerisinde değerlendirildiğinde nöro teknikler etik bir sorun olarak görülmemektedir.

Katılımcılara göre, nöropazarlama bir araç olarak görülmekte ve amacı kar elde etmek olan bir firma için veriler sunmaktadır. Özellikle ürün geliştirme kısmında tüketicinin istediği, ona gerçekten faydalı olabilecek ürünü keşfetmek için nöropazarlama uygulamalarını kullanmak etik açıdan bir sorun oluşturmamaktadır.

Konuya olumsuz yaklaşan katılımcılara göre; nöropazarlama alanı etik dışı davranma fırsatlarının yoğun olduğu bir alan olarak görülmektedir. Bu nedenle farklı amaçlarla kullanıldığında etik bir sorun oluşturabilmektedir. Bununla birlikte kullanılan cihazların radyasyon içermesi ve insan bedenine zarar vermesi de olası risklerden birisi olarak düşünülmektedir. Tıbbi amaçlı yan etkiler olmakla birlikte bunun ticari amaçlı olması kabul edilemez bir durumdur. Ayrıca, etik açıdan karşı çıkılmasındaki en önemli nedenlerden biri olarak; bireylerin beyinlerinin kendilerine özel olduğu ve buna herhangi bir amaçla girilmesinin etik olmayacağı görülmektedir.

Nöropazarlama çalışmalarında dikkat edilmesi gereken etik kurallar neler olmalıdır?

Araştırmaya katılan akademisyenlere yöneltilen bir diğer soru ise nöropazarlama çalışmalarında dikkat edilmesi gereken etik kuralların neler olması gerektiğine yöneliktir. Katılımcıların bu konuda ortak bir görüşe sahip oldukları görülmüştür. Buna göre; nöropazarlama araştırmalarında tüketicilerin deneylere katılmadan önce mutlaka onaylarının alınması, araştırmanın amacının net olarak anlatılmasının gerekliliği, uygulamanın mutlaka bir akademi altında gerçekleştirilmesi, katılımcıların hem deneyin aşamaları hem de kullanılacak cihazlar hakkında ayrıntılı şekilde bilgilendirilmesi gerekliliği temelde vurgulanmaktadır. Ayrıca; kullanılacak metotlar açık ve detaylı olarak belirtilmeli, araştırmayı yapacak kişiler gerçekten uzman olmalı, uygulanacak yöntemler deneklere gerek fiziksel gerekse zihinsel açıdan kesinlikle zarar vermemeli, elde edilen sonuçlar doğru yorumlanmalı ve çarpıtılmamalı, tüketicileri kandıracak şekilde kullanıımamalıdır. Ölçümlerin geçerlik ve güvenirliğini desteklemek için bağımsız ve objektif kanıtlar sağlanmalı ve çalışmalar yürütülürken çalışmayı gerçekleştirenler nöropazarlama araştırmasının bütünlüğünü ve itibarını negatif yönde etkileyecek davranışta bulunmaktan kaçınmalıdır. Çalışmalar sonunda elde edilen bulgular abartılmadan ve nöropazarlamayla ilgili yanlış algılara sebebiyet vermeden açıklanmalı ve müşterilere bu şekilde gönderilmelidir. Nörapazarlama araştırmaları çalışma amacı dışında kullanılmamalı ve kesinlikle gönüllü katılımı sağlanmalıdır. Nöropazarlama araştırmacıları nöropazarlama projesine katılan kişilerin kişisel bilgilerinin korunması ve katıımcıların hiçbir şekilde zarar görmemesi için gerekli önlemleri alma sorumluluğunda olmalıdır.

Bununla birlikte kurallar farklı alanlardaki uzmanlardan oluşan bir kurul tarafından 
oluşturulmalı, işletme, pazarlama, nöroloji, hukuk, psikoloji, istatistik uzmanları bu kurul içinde yer almalı, kurallar objektif olarak yazılmalıdır. Özellikle çocuklar üzerinde bu deneylerin gerçekleştirilmemesi toplum üzerinde olumsuz fikir oluşturacağı için dikkat edilmesi gereken bir husus olarak belirtilmektedir.

Nöropazarlama ile ilgili en önemli etik kaygı, pazarlamacıların tüketicilerin bilinçleri dışında herhangi bir ürünü satın almalarına yol açacak yöntemleri geliştirmelerdir. Tüketicilerin satın alma davranışlarının kişiden kişiye farklılık gösterdiği, bu nedenle kişiye özel reklamlara kadar pek çok yöntemin denendiği bir dünyada, tıpkı diğer araştırma yöntemlerinde olduğu gibi nöropazarlamadan elde edilecek verilerin kullanılmasına da dikkat edilmelidir.

Nöropazarlama önümüzdeki süreçte sıkça başvurulan yöntemlerden birisi olma yolunda ilerlemektedir. Bu noktada karşılaşılabilecek etik sorunlar doğrultusunda sizce ne gibi yasal önlemler alınmalıdır?

Nöropazarlamaya yönelik olarak ortaya çıkabilecek etik sorunlar doğrultusunda alınması gereken yasal önlemlere yönelik olarak katılımcılara yöneltilen soruda elde edilen veriler şu şekildedir: Genel geçer ve yaptırımları olan kurallarla birlikte denetim mekanizması olmalıdır. Nöropazarlama faaliyetlerini denetleyecek bir kurum oluşturulmalı ve ayrıca bu kurallar yasalarla da desteklenmelidir. Yasa sadece nöropazarlama uygulamaları için olabileceği gibi bilimsel araştırmalarda insan deneklerin kullanılmasına yönelik olarak geniş kapsamlı bir şekilde de olmasına yönelik bir görüş hâkimdir. Nöropazarlama açısından mikro ölçekli olarak düşünüldüğünde, bilgi vermeden araştırma yapmak, yanlış bilgi vermek, bilinçaltına girmek kişilik haklarına saldırı olarak kabul edilmelidir. Kişinin fiziksel, zihinsel açıdan zarar görmesi, maddi kayba uğraması durumları ceza kanundaki bu durumla ilgili maddelere göre yaptırımlara bağlanmalıdır. Nöropazarlama araştırmalarındaki tarafların (denek olarak katılanlar, diğer tüketiciler, uygulamayı yürüten işletmeler, diğer işletmeler vb.) herhangi bir olumsuzlukla karşılaşmaları durumunda haklarını yasalara dayanarak savunabilmeleri gerekmelidir. Araştırmayı yapan işletmeler ve denekler arasında sözleşme imzalanmalıdır.

Nöropazarlama teknikleri günden güne daha güçlü bir hal aldıkça sektör artan bir dirençle karşılaşmaktadır. Bu direnç tüketicilerin intiyaçları olmayan bir ürünü isteme yönündeki inanç yanılgıları olarak sürekli kendini hissettirecektir. Bu doğrultuda nöropazarlamanın ilk olarak standart bir uygulama şeklinde yasal statüye kavuşması gerektiği belirtilmektedir. Araştırmalar için ürün kategorisinden çeşitli kullanımlara kadar bir yasal düzenleme yapılması gerektiği ve doğal olarak araştırmaların kategorileştirilerek belirli bir yasal statüye dayandırılması nöropazarlamada amaç dışı kullanımının önüne geçmeyi engelleyeceği düşünülmektedir.

Nöropazarlama kullanım alanı ve uygulamasında gerekli olan öz düzenleme standartlarının geliştirilmesi, bu alanda yasal riskin azaltılmasında önemli bir rol oynayacaktır. Yasalar çerçevesinde nöropazarlama endüstrisinin göz önünde bulundurması gereken nokta; çocukları ve bunun gibi savunmasız grupları hedef almaktan kaçınmak olmalıdır. Bu durumun önüne geçebilmek için nöropazarlama çalışmalarını yapanlara gerekli sorumluluğu üstlenmeleri etik olarak belirtilmeli ve bu yasal çerçeveyle zorunlu olarak çizilmelidir. Araştırmaların ve uygulamaların tüketicileri istismar etmemesi için araştırmacılar ve nöropazarlama tekniklerini kullanan şirketlerin 
doğabilecek sonuçlardan dolayı maddi ve manevi sorumlulukları üstlenmeleriyle ilgili yasalar oluşturulmalıdır.

Ayrıca konunun aktörleri arasında karşılıklı olarak belirli standartlar belirlenmelidir. Özellikle deneklerin gönüllü katılımları ve bu alanda araştırma yapacak kurumların mutlaka etik kurullarının oluşturulması gerekmektedir. Etik kuruldan onay almayan hiçbir araştırma uygulanmamalıdır. Etik kurul raporu alınması zorunlu ve yasal hale getirilmelidir. Yasalar ile deneğin haklarının neler olacağı mutlaka bir sözleşme ile belirlenmelidir. Bu türden çalışmalar sağlık bakanlığı ve nörologlardan oluşan bir komisyonun izni olmaksızın yapılmamalıdır. Devlet mutlaka nöropazarlama araştırmaları yapmak isteyen firmaları kontrol edecek yetkili merciler oluşturmalı ve firmaların izleyeceği, kılavuz niteliği taşıyacak standartlar geliştirmeli ve araştırma sonuçlarının kötüye kullanılması kesinlikle önlenmelidir.

Bilim adamlarının Nöropazarlama konusuna tedirginlikleri bulunmaktadır. Bu konudaki bir düşüncede "Etik olarak doğru bulmayanların sayısı fazla olmakla birlikte temel endişeleri Nöropazarlama tekniklerinin insanların zayıf noktalarını bulması ve daha sonra insanlara bu açıdan yaklaşılıp daha çok ürün satılmasına yönelik alternatifler sunmanın yolunu bulmasıdır. Yani temel olarak insana bir faydası dokunmamakla birlikte tüketiciye daha fazla para harcatmaya odaklanmaktadır." Sizin bu konudaki yorumlarınız nedir?

Araştırmaya katılanlara göre; kötü niyetli kullanacak insanlara olanak sağlayabilir ancak yasal sınırlar alınarak bunun önüne geçilebilir. Nöropazarlama, gerçekten pazarlama amaçlarına ulaşmakta çok faydalı bir araç olarak görülmektedir. Çünkü anketler yoluyla tüketicilerin cevaplarken çelişkide kaldığı, geçiştirdiği ya da yanlış yanıtladığı soruların cevaplarını bu yöntemle daha net ve kesin bir biçimde almak mümkündür. Katılımcılara göre, etik kurallara uyulduğu, tüketiciye zarar vermediği ve sonuçların kötüye kullanılmadığı sürece uygulanabileceği belirtilmektedir.

Yukarıda savunulan düşüncenin pazarlama faaliyetlerinin odağını oluşturduğunu savunan bir görüşe göre insanlar sadece intiyaçları doğrultusunda hareket etmemektedir ve bunun en önemli sebebi, tüketiciye intiyacından fazlasını satın aldırmaya yönelik olarak yapılan pazarlama faaliyetleridir. Çünkü, pazarlamanın temelinde ürünlerin tüketiciler tarafından satın alınmasının sağlanması yatmaktadır ve tüm tutundurma çalışmalarının odak noktası budur. Bu açıdan bakıldığında; nöropazarlamanın da diğerlerinden bir farkı bulunmamaktadır. Bu türden uygulamalar tüketicilerin bir ürünü neden satın aldıklarını açıklayabilmek adına pazarlamacılar için oldukça faydalıdır. Tüketicilerin satın alımlarını tetikleyen pek çok faktör bulunmaktadır. Bunlar; öğrenme, algı, motivasyon ve tutumu içeren psikolojik faktörler, sosyal ve kültürel faktörler olarak sıralanmaktadır. Pazarlama açısından bakıldığında, zaten tüm faktörleri oluşturan kuramlardan günümüzde yararlanılarak mağaza atmosferi oluşturulmakta, görsel tasarımlar, vitrin dizaynları gerçekleştirilmektedir. Tüm bunları değerlendirdiğimizde ise; nöropazarlama olmasa bile zaten toplumun tüketim toplumu haline getirilmeye çalışıldığı gözlemlenmektedir. Pazarlamacılar açısından diğer araştırma yöntemlerine kıyasla tüketici hakkında daha net bilgiler sunan nöropazarlamada ise sadece bunlardan birisidir. Bu nedenle toplumsal pazarlama anlayışı çerçevesinde tüketici isteklerine odaklanıldığında insanların beyinlerinin bu tepkileri üzerinden hareket ediyor olmanın olumlu sonuçlar doğuracağı düşüncesi katılımcılar tarafından ön plana çıkmaktadır. 
Nöropazarlama uygulamalarına yönelik olarak belirtilen bir başka düşünceye göre; uygulamanın kullanım amacının önemli olduğu düşüncesi hâkimdir. Bu noktada asıl amaç hedef kitlenin ihtiyacını karşılamak mı yoksa ihtiyaç üretip para kazanmak mı? sorusunun cevabıdır. Kullanımamacı bireyin ihtiyacınayönelikse ve bireyin bu ihtiyacının karşılanması halinde birey mutlu olacaksa yapılan nöropazarlama araştırmaları etik olarak düşünülmektedir. Amaç tamamen tüketiciyi sömürmek, tüketicinin ihtiyaçlarını bir kenara bırakıp elde edilen bilgilerle ürün satımını kolaylaştırmak ve sonucunda kar sağlamayı hedeflemekse nöropazarlamanın etik prensiplerinden bahsedilemeyeceği ve aradaki ince çizgileri net bir şekilde belirlemek söz konusu bilim adamlarının tedirginliklerini gidereceği dile getirilmektedir.

Nöropazarlama kavramı bilimsel bir araç olarak ilk kez ortaya atıldığında uygulamaların insan davranışlarını daha iyi ve doğru anlamaya yardım edebileceği düşüncesinden yola çıkıldığına inanılmaktadır. 1990'ların sonunda temeli atılan bu tür bir uygulama 2002 'de kavram olarak kullanılmıştır. Yeni geliştirilen bir şey bilinmediği için insanlarda korku ve tedirginlik yaratabilmektedir. Bu nedenle nöropazarlamanın insanlarda tedirginlik uyandırabileceğini kabul edilmektedir. Özellikle işin içine işletmeler girince bu tedirginlik artmakta ve tüketicilerin gözünde sadece kar amacı güden kuruluşlar olarak görülmektedir. Diğer bir deyişle işletmelerin genel olarak tüketici gözündeki imajı bu tedirginliği arttırmaktadır. Katılımcılara göre, objektif ve uzman bir denetim mekanizması oluşturularak uygulamalar kontrol altında tutulursa tedirginlik yaratacak bir durum oluşmayacaktır. Görüşün aksini savunanlara göre ise; nöropazarlama çalışmaları tüketicileri kontrol altına alma ve her şeyi bir intiyaçmış gibi göstererek daha fazla para harcatmaya yönelik çalışmalar olarak görülmektedir.

\section{Sonuc}

Nöropazarlama, beyin görüntüleme tekniklerinin kullanılmasıyla tüketicilerin karar ve tercihlerini anlamaya açıklamaya çalışan disiplinler arası (veya çok disiplinli) giderek gelişmekte olan bir bilimsel alan olarak karşımıza çıkmaktadır. Nöropazarlama kavramı, firmalar açısından sağladığı avantajlar doğrultusunda her geçen gün yaygınlık kazanmakta ve bu sayede tüketiciler ile marka arasında daha olumlu ilişkiler kurulmaya çalışılmaktadır. Nöropazarlama uygulamaları tüketiciyle onun istek ve beklentiler doğrultusunda duygusal bir bağın oluşmasına katkıda bulunmakta, elde edilen bilgiler doğrultusunda uygun stratejiler geliştirilmesini sağlamakta ve uzun dönemli ilişkilerin gelişmesini kolaylaştırmaktadır. Ayrıca, tüketici ile kurulacak duygusal bağın yollarını göstermek noktasında önemli katkılar sağlamaktadır.

Nöromarketing teknikleri ile tüketicinin düşünce ve isteklerinin daha doğru anlaşılabileceği hem pazarlama profesyonelleri hem de tüketici için bunun avantaj sağlayacağı, bu sayede markaların daha iyi ürün ve hizmetler ortaya çıkabileceği düşünülmektedir. Geleneksel pazarlama yöntemlerinin yerine artık daha yaratıcı ve tüketiciye dokunabilen yöntemler geliştirilebilmenin önemli olduğu bir dönemde nöroteknik uygulamalar bunun için önemli avantajlar sunmaktadır. Ancak, birçok avantajı olmasına rağmen uygulanmasının zor ve masraflı olmasından dolayı kolay olmadığını belirtmekte de fayda görülmektedir.

Pazarlama alanın yeni uygulamalarından biri olan nöropazarlamaya yönelik olarak destekleyenler olduğu kadar karşı çıkanlarda vardır. Özellikle nörologlar nöro 
tekniklerin pazarlamada kullanımına etik açıdan karşı çıkmakta ve tüketicinin gizli bölgesinin pazarlama amaçlı kullanılmasının doğru olmadığını savunmaktadır. Tüketicinin "beynindeki satın alma düğmesini" (buy button in the brain) bulmak ve bireyin direnemeyeceği reklâm kampanyaları oluşturmanın etik olarak uygun olmadığını belirtilmektedir.

Ancak akademisyen tarafına geçtiğimizde ise; bu tekniklerin kullanılmasının yasal zeminleri oluşturulduğu sürece herhangi bir sıkıntı oluşturmayacağı görüşü hâkimdir. Nöropazarlama üzerine çalışmış akademisyenler; bilimin zaten yıllardır pazarlama faaliyetlerinin daha iyi sonuçlar vermesi için kullanıldığını ve nöropazarlamanın da bunlardan biri olduğunu savunmaktadır. Ayrıca, bu tekniklerin kullanılmasıyla tüketici intiyaç ve isteklerinin doğru şekilde anlaşılıp bu doğrultuda ürün ya da hizmetler geliştirilebileceğini, daha somut bilgiler sunacağını, gereksiz harcamaları ortadan kaldırılacağını belirtmektedirler. Burada dikkat edilmesi gereken en önemli noktalar; çalışmaların yasal bir zemin içinde gerçekleştirilmesi, deneklerin doğru ve yeterince bilgilendirilmesinin gerekliliği ve ayrıca deneklerden elde edilen bilgilerin şirketlerin hangi amaçla, ne kadarını, ne ölçüde kullanabilecekleri konusudur. Elde edilen veriler yasal zeminler çerçevesinde doğru şekilde kullanıldığında nöropazarlama uygulamalarının firmalara birçok yönden önemli avantajlar sağlayacağı düşünülmektedir. En önemli katkısının ise; hedef kitlenin doğru anlaşılıp isteklerinin net şekilde tespit edilmesi ve buna uygun ürünler üretilmesine yardımcı olacağı görüşüdür.

Çalışmada elde edilen bilgiler doğrultusunda eğer yasal zeminleri doğru şekilde yapılandırılırsa nöropazarlamada nöro tekniklerin kullanılması deneklerin tüm koşulları bilmesi ve kabul etmesi durumunda etik bir sıkıntı ortaya çıkarmayacaktır. Bununla birlikte eğer yasal zeminlere dayandırılmaz ise; ileride insanın kendisinin bile bilmediği, yönetemediği kısmı ile bilimin uğraşmasının ve bunun ele geçirilmesinin tehlikeli boyutlara ulaşabileceğini de dikkate almak gerekmektedir. Katılımcıların bazıları insanlığın faydasına yönelik bulunan bu tekniklerin iyi niyetle kullanılmasının herhangi bir problem ortaya çıkarmayacağını savunmaktadır. Ayrıca katılımcılar bu konuda yapılan çalışmalar için mutlaka deneklerden izin alınmasının gerekliliğine vurgu yapmaktadır. Özellikle tüketicinin ihtiyacını önceden bilip buna yönelik ürünler geliştirmenin işletmeler açısından gereksiz harcamaları ortadan kaldıracağı düşünülmektedir.

Nörotekniklerin uygulanması sırasında izin alınmasında ücret ödemenin sonuçların güvenirlilik ve tutarlılığını ne ölçüde etkileyeceğine yönelik olarak; bu tekniklerin uygulanmasında gönüllülük esasının uygulanmasının diğer tekniklere göre (anket, görüşme vb.) daha zor olmakla birlikte belli bir çaba ve zaman harcanması gerekmektedir. Ancak bununla birlikte elde edilen bilgilerin geleneksel araştırma yöntemlerine göre daha somut olduğu düşünüldüğünde özellikle tüketicinin satın alma kararı verirken neleri ön planda tuttuğu, duygusal mı yoksa rasyonel mi karar verdiği gibi konularda pazarlama uzmanlarına önemli veriler sunması bu çabaya değer olduğunu göstermektedir.

Nöromarketing tekniklerinde eğer yeterli imkân bulunur ve yeterli sayıda kişiye uygulanırsa sonuçlar tüketicinin anlaşılması için çok fayda sağlayacağı ve pazarlama için bir devrim niteliğinde olacağına söylemek yanlış olmayacaktır. Nörotekniklerin pazarlama alanında etik açıdan doğru şekilde kullanılması için nörolojistler, pazarlama 
alanında uzman akademisyenler/sektör temsilcileri, tüketici haklarını savunacak kurulların ortaklaşa bir çalışma yapması etik alandaki kaygıları ortadan kaldırılmasına yardımcı olacaktır.

\section{Kaynakça}

Ariely, Dan, ve Gregory S. Berns (2010). "Neuromarketing: the Hope and Hype of Neuroimaging in Business." Nature Reviews Neuroscience. 11(4): 284-292.

Burgos- Campero, A. Asela ve Vargas- Hernandez, Jose G. (2013). "Analitical Approach to Neuromarketing as a Business Strategy." Procedia - Social and Behavioral Sciences 99: 517 525.

Çakar, Tuna ve Ülman, Yeşim Işı (2012). "Nöropolitika ve Etik." (Ed: Yeşim Işı ÜIman, Fatih Artvinli). Değişen Dünyada Bioetik. Türkiye Biyoetik Derneği Yayını. 18: 326-343.

Eser, Zeliha; Işin, F. Bahar ve Tolon, Metehan (2011). "Perceptions of Marketing Academics, Neurologists, and Marketing Professionals About Neuromarketing." Journal of Marketing Management. 27(7-8): 854-868.

Fisher, Carl Erik; Chin, Lisa ve Klitzman, Robert (2010). "Defining Neuromarketing: Practices and Professional Challenges." Harvard Review of Psychiatry. 18(4): 230-237.

Hatip, Murat (2008). "Neuro Marketing". https://marketrend.wordpress.com/2008/11/16/neuro-marketing/. (Erişim tarihi: 03.06.2014).

Laczniak, Gene R. (1983 ). "Framework for Analyzing Marketing Ethics." Journal of Macromarketing. 3(1): 7-18.

Lee, Nick; Broderic, J. Amanda ve Chamberlain, Laura (2007). "What is 'Neuromarketing'? A Discussion and Agenda for Future Research." International Journal of Psychophysiology. 63: 199- 204.

Lindstrom, Martin (2011). Buyology (1.basım). İstanbul: Optimist.

Morin, Christophe (2011)."Neuromarketing: the New Science of Consumer Behavior." Society. 48(2): 131-135.

Murphy R, Emily; Illes Judy; Reiner B. Peter (2008). "Neuroethics of Neuromarketing" Journal of Consumer Behaviour. 7: 293-302.

Müdok, Tangül (2013). Nöronal Pazarlama: Nöromarketing. http://www.sdplatform.com/Dergi/747/ Noronal-pazarlama-Noromarketing.asp (Erişim tarihi: 01.06.2014).

Özdemir, Erkan (2009). "Pazarlama Araştırmasında Etik Karar Alma." Ankara Üniversitesi SBF Dergisi. 64(02): 119-144. 
Pop Nicolae Al; Dabija Dan Cristian ve lorga, Ana Maria (2014). "Ethical Responsibility Of Neuromarketing Companies in Harnessing The Market Research- AGlobal Exploratory Approach" (Electronic Version). Amfiteatru Economic. 16(35): 26-40.

Sreedevi, V.; Jayasree, K.V. ve Auguskani, P. Lovelin (2013). "Neuro Marketing: An Effective Marketing Strategy." International Journal of Marketing and Technology. 3(6): 63.

Tüzel, Nazlım (2010). "Tüketicilerin Zihnini Okumak: Nöropazarlama ve Reklam." Marmara İletişim Dergisi. 16: 163-176.

Ural, Tülin (2008). "Pazarlamada Yeni Yaklaşım: Nöropazarlama Üzerine Bir Değerlendirme." Çukurova Üniversitesi Sosyal Bilimler Enstitüsü Dergisi. 17(2): 421-432.

Wilson, R. Mark; Gaines, Jeannie ve Hill, Ronald Paul (2008). "Neuromarketing and Consumer Free Will." Journal of Consumer Affairs. 42(3): 389-410.

Yıldırım, Ali ve Şimşek, Hasan (2008). Nitel Araştırma Yöntemleri. (7. Baskı). Ankara: Seçkin.

Yücel, Atilla ve Çubuk, Fatma (2013). "Nöropazarlama ve Bilinçaltı Reklamcılık Yaklaşımlarının Karşılaştırılması." Niğde Üniversitesi IïBF Dergisi. 6(2): 172-183. 